\title{
POLA PENAMPANG LINTANG MAKROSKOPIK TOTAL DALAM SEL BAHAN BAKAR NUKLIR
}

\author{
Nurul Aini, Mohamad Ali Shafii, Ardian Putra \\ Jurusan Fisika FMIPA Universitas Andalas \\ Kampus Limau Manis, Padang 25136 Po Box 143 \\ Email: Nurul88aini16@yahoo.com
}

\begin{abstract}
ABSTRAK
Penampang lintang makroskopik memiliki peranan penting dalam menghitung transport neutron yang terjadi pada reaktor nuklir. Hasil penampang lintang digunakan untuk menghitung nilai distribusi fluks neutron yang terjadi di teras reaktor. Penelitian ini menampilkan nilai penampang lintang makroskopik total dari sebuah sel bahan bakar nuklir. Tahap awal dilakukan dengan menentukan bahan bakar yang digunakan yaitu uranium-plutonium nitride, kemudian fraksi massa dan fraksi volume, cladding, dan pendingin. Perhitungan penampang lintang makroskopik ini dilakukan dengan metode simulasi komputer menggunakan bahasa pemrograman Borland Delphi 7.0. Program yang digunakan adalah program homogenisasi sel dengan data library JFS-3-J33 dari JAEA (Japan Atomic Energy Agency) yang menghasilkan nilai penampang lintang makroskopik total untuk 70 grup energi. Hasil analisis menunjukan bahwa pola penampang lintang makroskopik total untuk nuklida uranium dan plutonium pada energi tinggi (unresolved resonance) mengalami tumpang tindih (overlap) dalam sel bahan bakar nuklir.
\end{abstract}

Kata Kunci: penampang lintang makroskopik total, sel bahan bakar nuklir, energi grup neutron, daerah resonan

\begin{abstract}
Macroscopic cross section has an important role in the neutron transport calculation that occurs in a nuclear reactor. The result of the cross section is used to calculate the neutron flux distribution in the reactor core. This study presents the total macroscopic cross section pattern of a nuclear fuel cell. The initial work is the selection of uranium-plutonium nitride as fuel, followed by mass fraction, volume fraction, cladding and coolant. The macroscopic cross section calculations is performed with computer simulation method using Borland Delphi 7.0. The program used a cell homogenization code with a data library JFS-3J33 from JAEA (Japan Atomic Energy Agency) that generates the value of the total macroscopic cross section for 70 groups of energy. The analysis showed that the total macroscopic cross section of uranium and plutonium nuclides in high energy (unresolved resonance) overlap in the of nuclear fuel cell.
\end{abstract}

Key words : total macroscopic cross section, nuclear fuel cell, neutron energy group

\section{PENDAHULUAN}

Nilai penampang lintang sangat diperlukan dalam pengaplikasian fisika reaktor. Untuk mengetahui perilaku neutron dan nuklida dalam reaktor, perlu dilakukan perhitungan probabilitas dari interaksi neutron dan nuklida yang terjadi dalam teras reaktor. Peristiwa tumbukan antara neutron dengan inti dapat menyebabkan berbagai macam reaksi. Untuk mengetahui kuantitas dari masing-masing reaksi tersebut didefinisikan sebuah penampang lintang makroskopik dengan cara mengukur probabilitas masing-masing reaksi di tiap energi grupnya. Data penampang lintang yang diperoleh akan digunakan untuk analisis pada reaktor nuklir. Perilaku dari tiap penampang lintang sangat penting agar analisis reaktor nuklir lebih efektif. 
Perkembangan penelitian yang menyangkut disain reaktor membawa konsekuensi pada aspek komputasinya. Bila pada awal perkembangan reaktor nuklir, eksperimen mendominasi dalam upaya pemecahan masalah tentang reaktor nuklir, maka pada saat ini aspek komputasi memegang peranan yang sangat penting. Sebagian besar tahap awal dan tahap perencanaan detil dalam disain reaktor nuklir umumnya dikerjakan dalam bentuk komputasi.

Penelitian ini bertujuan untuk memperoleh karakteristik penampang lintang makroskopik yang terjadi dalam sel bahan bakar nuklir pada jenis reaktor cepat berpendingin $\mathrm{Pb}-\mathrm{Bi}$ dan berbahan bakar uranium-plutonium nitride. Analisis dilakukan untuk memperoleh prilaku penampang lintang berdasarkan energi grup.

\section{a. Penampang Lintang Mikroskopik}

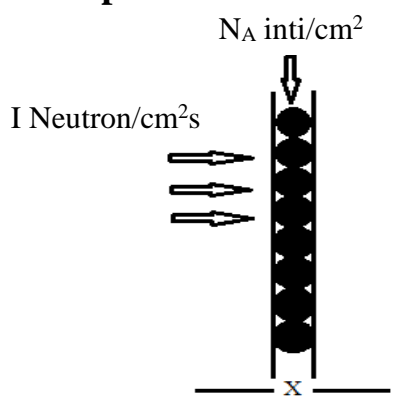

Gambar 1. Seberkas neutron datang pada sebuah bahan tipis

(Obara, 2012)

Pada Gambar 1 terlihat seberkas neutron datang pada sebuah bahan, dengan intensitas fluks neutron yang datang (I neutron $\left./ \mathrm{cm}^{2} . \mathrm{s}\right)$ dan kerapatan atom $\left(N_{A} / \mathrm{cm}^{3}\right)$. Untuk suatu lapisan yang tipis dapat diharapkan bahwa laju interaksi akan sebanding dengan fluks neutron datang dan juga sebanding dengan kerapatan atom per luas penampang $\left(N_{A} d x\right)$, seperti pada Persamaan I.1 (Duderstadt dan Hamilton, 1976):

$$
R=\sigma I N_{A}
$$

\section{b. Penampang Lintang Makroskopik}

Penampang lintang makroskopik $(\Sigma)$, yaitu kebolehjadian suatu reaksi atau interaksi nuklir akan terjadi pada sebuah material atau suatu bongkah unsur yang terdiri dari beberapa atom dengan kerapatan $N$ atom $/ \mathrm{cm}^{3}$. Satuan penampang lintang makroskopik adalah $\mathrm{cm}^{-1}$.

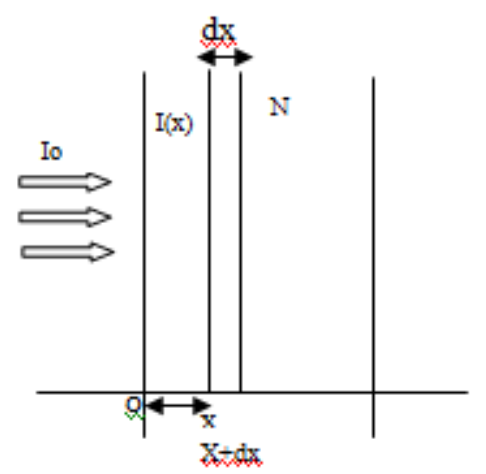

Gambar 2. Seberkas neutron datang pada sebuah material (Obara, 2012) 
Gambar 2 memperlihatkan seberkas neutron yang diarahkan ke sebuah bahan yang mempunyai ketebalan $\mathrm{x}$ dan $\mathrm{x}+\mathrm{dx}$, dimana dalam elemen tipis $\mathrm{dx}$ terdapat partikel $\mathrm{N}$, dengan laju reaksi total di daerah dx pada Persamaan I.2 dan hubungan penampang lintang makroskopik dengan penampang lintang mikroskopik pada Persamaan I.3 (Duderstadt dan Hamilton, 1976):

$$
\begin{aligned}
& d R=\sigma_{t} I N d x \\
& \Sigma=\sigma N
\end{aligned}
$$

Penampang lintang makroskopik pada sel bahan bakar yang telah terhomogenisasi ditentukan oleh peristiwa berikut ini (Nakagawa dan Tsuchihashi, 1984) :

Penampang lintang serapan makroskopik pada setiap grup energi gdapat dilihat pada Persamaan I.4

$$
\sum_{a}^{g}=\frac{\sum_{i}\left(\sum_{f, i}^{g}+\sum_{c, i}^{g}\right) \phi_{i}^{g} V_{i}}{\sum_{i} \phi_{i}^{g} V_{i}}
$$

dengan $\phi_{i}$ dan $V_{i}$ adalah fluks neutron dan volume pada region $i$, dan $\sum_{c, i}^{g}$ merupakan penampang lintang tangkapan (capture) untuk setiap grup energi $g$ pada region ke $i$. Penampang total makroskopik pada setiap grup energi $g$ seperti Persamaan 1.5

$$
\sum_{t}^{g}=\frac{\sum_{i} \sum_{t, i}^{g} \phi_{i}^{g} V_{i}}{\sum_{i} \phi_{i}^{g} V_{i}}
$$

Penampang lintang hamburan makroskopik pada setiap grup energi gpada Persamaan 1.6

$$
\sum_{s}^{g}=\sum_{t}^{g}-\sum_{a}^{g}=\left(\sum_{e l}^{g}+\sum_{i n}^{g}+\sum_{n 2 n}^{g}\right)
$$

dengan $\sum_{e l}^{g}, \sum_{i n}^{g}, \sum_{n 2 n}^{g}$ berturut-turut adalah penampang lintang elastik, inelastik dan reaksi $n 2 n$.

\section{II. METODE PENELITIAN}

Bahan bakar yang digunakan dalam penelitian ini adalah uranium-plutonium nitride, bahan struktur kelongsongnya adalah stainless steel dan $\mathrm{Pb}-\mathrm{Bi}$ sebagai pendingin. Untuk melihat spesifikasi disain sel bahan bakar nuklir pada penelitian ini dapat dilihat pada Tabel 1.

Penelitian ini dilakukan dengan metode simulasi komputasi menggunakan bahasa pemograman Borland Delphi 7.0. Program yang digunakan adalah program homogenisasi sel. Perhitungan penampang lintang makroskopik diterapkan pada model sel bahan bakar nuklir berbentuk silinder satu dimensi dengan 70 grup energi.

Data library yang digunakan dalam penelitian ini adalah JFS-3-J33 dari JAEA (Japan Atomic Energy Agency). Library ini menyediakan grup konstan bagi komputer SLAROM. 
Tabel 1. Spesifikasi disain sel bahan bakar nuklir(Shafii, dkk., 2012)

\begin{tabular}{|l|c|}
\hline \multicolumn{1}{|c|}{ Parameter } & Spesifikasi \\
\hline Bahan bakar & uranium-plutonium nitride \\
\hline Bentuk sel & Silinder 1D \\
\hline Struktur material & Stainless steel \\
\hline Pendingin & Timbal-Bismuth $(\mathrm{Pb}-\mathrm{Bi})$ \\
\hline Diameter pin bahan bakar & $1,134 \mathrm{~cm}$ \\
\hline Tebal cladding & $0,11 \mathrm{~cm}$ \\
\hline Temperature rata-rata & $1383 \mathrm{~K}$ \\
\hline Fraksi volume sel: bahan bakar & $61,73 \%$ \\
& Struktur \\
pendingin & $19,49 \%$ \\
\hline
\end{tabular}

Secara umum langkah kerja pada penelitian ini dimulai dengan langkah-langkah persiapan yaitu menetapkan spesifikasi disain reaktor yang akan disimulasikan pada file data masukan (input). Proses perhitungan diawali dengan menghitung homogenisasi sel untuk mendapatkan nilai penampang lintang awal total dan penampang efektif, kemudian dilanjutkan dengan perhitungan collision probability $\left(P_{i j}\right)$ untuk menghitung nilai volume tiap region. Perhitungan penampang lintang makroskopik merupakan hasil perkalian densitas atom di input pada program dengan nilai penampang lintang mikroskopik yang telah dihitung sebelumnya melalui penelitian Shafii, dkk., (2008).

Penghitungan penampang lintang makroskopik dimulai dengan membaca nilai penampang lintang awal total yang dihitung dari proses homogenisasi sel bahan bakar nuklir, dilanjutkan dengan membaca nilai volume untuk setiap region dan membaca nilai penampang lintang latar dari proses homogenisasi sel. Proses terus dilanjutkan sampai nilai divis $>0\left(\phi_{i} V_{i}>0\right)$, lalu dilanjutkan dengan menghitung penampang lintang makroskopik seperti yang ditunjukkan pada diagram alir perhitungan penampang lintang pada Gambar 4.

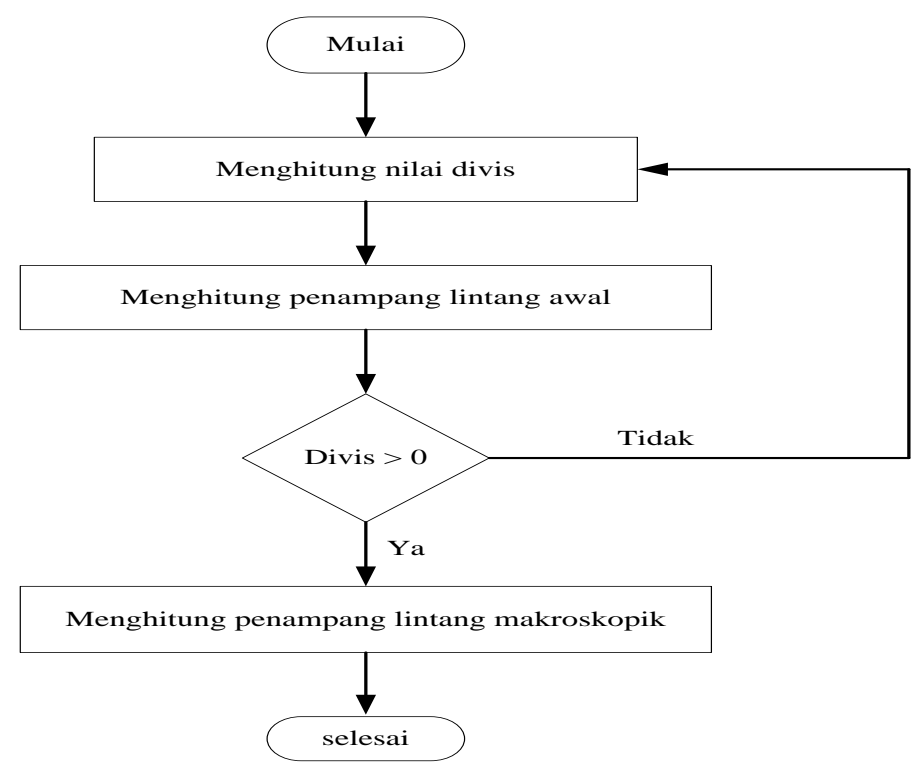

Gambar 4. Diagram alir perhitungan penampang lintang. 


\section{HASIL DAN PEMBAHASAN}

Berikut ini adalah hasil perhitungan untuk mendapatkan perilaku penampang lintang makroskopik total berdasarkan analisis multigrup energi.

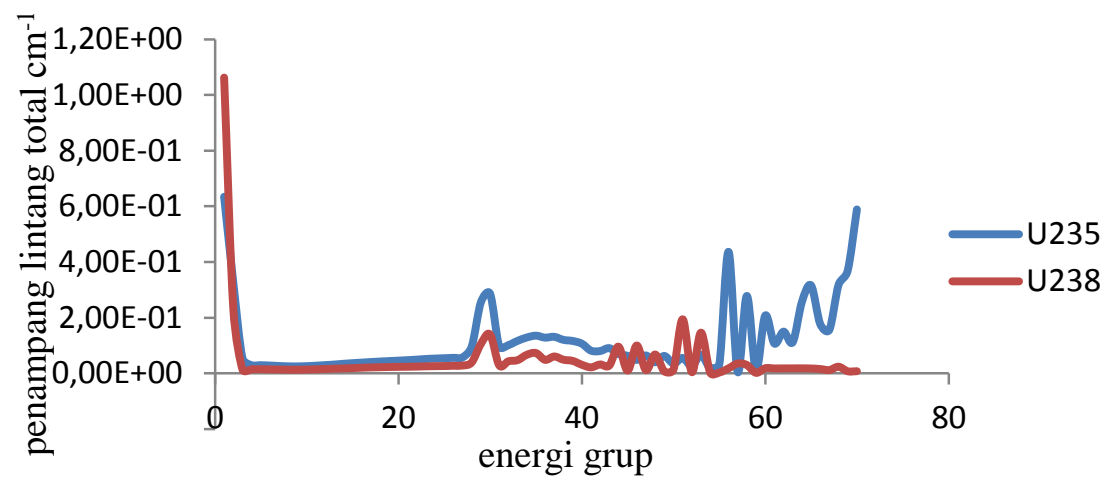

Gambar 5.Penampang lintang total $U^{235}$ dan $U^{238}$

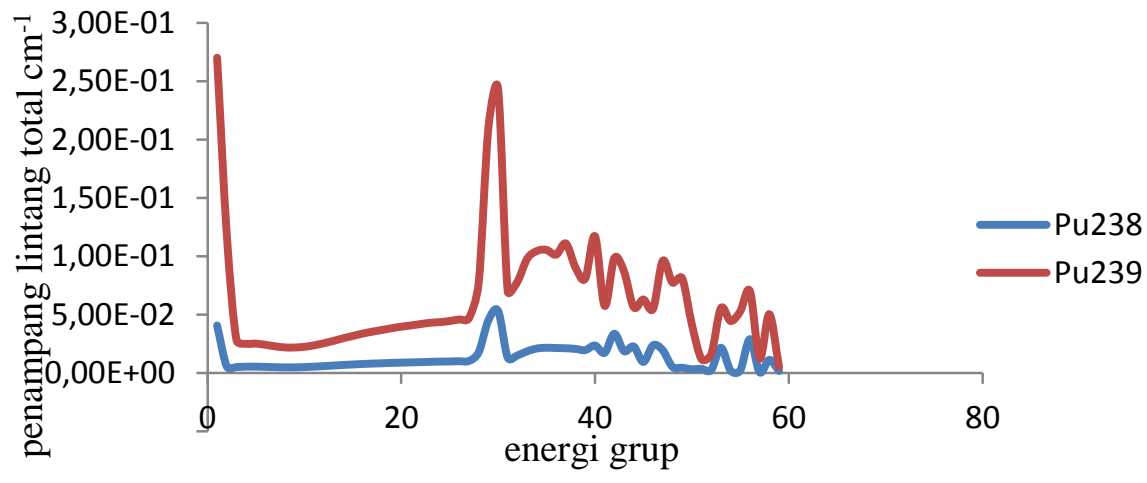

Gambar 6. Penampang lintang total $\mathrm{Pu}^{238}$ dan $\mathrm{Pu}^{239}$

Daerah resonan untuk penampang lintang total makroskopik ${ }^{235} \mathrm{U}$ dan ${ }^{238} \mathrm{U}$ terjadi pada energi grup ke 29 sampai grup 70, atau berada pada kisaran energi rendah $1 \mathrm{eV}$ sampai 1 $\mathrm{keV}$. Daerah resonan adalah karakteristik energi di mana nuklida mudah untuk tereksitasi yang ditandai dengan adanya penampang lintang yang sangat berbeda dengan rentang energi yang sangat dekat. Pada Gambar 5 terlihat bahwa penampang lintang total makroskopik ${ }^{235} \mathrm{U}$ dan ${ }^{238} \mathrm{U}$ pada daerah energi tinggi grafiknya cenderung lurus dan resonansi tetap terjadi, namun terlalu overlap. Pada energi tengahan (intermediate), penampang lintang total ${ }^{235} \mathrm{U}$ dan ${ }^{238} \mathrm{U}$ mengalami resonansi, yang ditandai dengan banyaknya puncak di daerah ini.

Pada reaktor, perubahan daerah resonan terjadi karena adanya perubahan suhu pada bahan bakar akibat pelebaran Doppler (Bell dan Glasstone, 1970). Pada energi tinggi atau unresolved resonance terjadi tumpang tindih (overlap) yang sangat kuat, oleh karena itu pelebaran Doppler hanya menghasilkan sedikit perubahan. Untuk reaktor cepat, banyak neutron memiliki energi di daerah unresolved resonance ini.

Gambar 6 memperlihatkan terjadinya tumpang tindih (overlap) yang sangat kuat di daerah energi tinggi pada penampang lintang total untuk nuklida ${ }^{238} \mathrm{Pu}$ dan ${ }^{239} \mathrm{Pu}$. Untuk reaktor cepat, sebagian besar neutron memiliki energi di daerah energi tinggi (unresolved resonance). Penampang lintang makroskopik total merupakan jumlah dari penampang lintang makroskopik serapan (absorpsi) dan penampang lintang makroskopik hamburan (scattering). 
Pembagian grup energi terbagi dari energi tinggi diwakili oleh grup 1 sampai 19, energi menengah diwakili oleh grup 20 sampai 37, sedangkan energi rendah diwakili oleh grup 38 sampai grup 70 .

\section{KESIMPULAN DAN SARAN}

Dari hasil homogenisasi sel bahan bakar nuklir pada reaktor cepat dengan bahan bakar uranium-plutonium nitride dan pendingin $\mathrm{Pb}-\mathrm{Bi}$, didapatkan grafik penampang lintang makroskopik total untuk nuklida uranium dan plutonium mengalami tumpang tindih (overlap) di daerah energi tinggi (unresolved resonance), memberikan hasil yang sesuai dengan referensi yaitu neutron cepat bereaksi pada energi tinggi.

\section{DAFTAR PUSTAKA}

1. Bell, G, dan Glasstone, S. 1970, Nuclear Reactor Theory, Van Nostrand Reinhold Company, New York.

2. Duderstad, JJ., dan Hamilton, L.J. 1976. Nuclear Reactor Analisys, Jhon wiley and Sons, New York.

3. Nakagawa, M., dan Tsuchihashi, K,. 1984. SLAROM : A Code For Cell Homogenization Calculation Of Fast Reactor. Department of Reactor Engineering, Tokai Research Institute.

4. Obara,T, 2012, Special Education Course On Nuclear Engineering By The University Network In Japan For Global Nuclear Human Resource Development, Tokyo institute of technology, Bandung, Indonesia.

5. Okumura, Kugo, T., Kaneko,K., and Tsichihashi,K. 2007. SRAC 2006 : A Chomprehensive Neutronics Calculation Code system, JAEA.

6. Shafii, M.A., Su'ud, Z. Waris, A., dan Kurniasih, N., 2008, Development of Cell Homogenization Code With Collision Probability Method, International Conference on Mathematics and Natural Sciences (ICMNS) 2008, ITB, Bandung.

7. Shafii, M.A, 2012, Nuclear Fuel Cell Calculation Using Collision Probability Method with Linear Non Flat Flux Approach, World Journal of Nuclear Science and Technology, 2012, 2, 49-53

8. Su'ud,Z. 1998. Kode Computer Homogenisasi Sel Bahan Bakar Pada Reaktor Cepat. Jurusan Fisika, ITB 